\title{
Selection among and within and combined selection in oil palm families derived from Dura x Dura
}

\author{
Seleção entre e dentro e seleção combinada em famílias de dendê oriundas do cruzamento \\ Dura x Dura
}

\author{
Digner Santiago Ortega Cedillo ${ }^{\mathrm{I}}$ Fábio Medeiros Ferreira ${ }^{\mathrm{II}}$ Willian Silva Barros ${ }^{\mathrm{II}}$

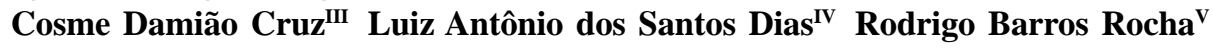

\begin{abstract}
Oil palm, in view of the worldwide consumed oil, is a perennial crop of great importance. Nevertheless, the genetic improvement is still incipient. In this study we applied the selection among and within families and the combined selection, based on the phenotypic values and phenotypic performance $\left(P_{i}\right.$ statistic), to verify which strategy obtained the highest genetic gains. Five full-sib families were evaluated in randomized blocks, with five replicates and 12 plants per plot, over five years of successive harvests. The total number of bunches and the total fruit yield per year plant ${ }^{1}$ were evaluated. Values of 1.00 and 0.25 for the ratio between the environmental variance among plots and the environmental variance among plants within the plot for both traits, respectively, were adequate for the estimation of the genetic parameters. The existence of genetic variability in the population Dura was verified for both evaluated traits. The combined selection, based either on the phenotypic values or on the underlying $P_{i}$ statistic, resulted in the highest genetic gains. Despite the satisfactory gains since it translates the true yield potential of the evaluated genotypes and their performance stability.
\end{abstract}

Key words: Elaeis guineensis Jacq., family test, selection strategies, $P_{i}$ statistic.

\section{RESUMO}

O dendê é uma cultura perene de grande importância devido à produção de óleo que é consumido mundialmente. Contudo, o melhoramento genético ainda é incipiente. Neste trabalho foram utilizadas a seleção entre $e$ dentro de famílias e a seleção combinada, a partir dos valores fenotípicos e da performance fenotípica (estatística $P_{i}$ ), visando verificar com qual das estratégias foi obtido maior ganho genético. Avaliaram-se cinco famílias de irmãos-completos em blocos casualizados, com cinco repetições e 12 plantas por parcela, durante cinco anos de colheitas sucessivas. O número total de cachos e a produção total de frutos por ano planta ${ }^{-1}$ foram avaliados. Valores de 1,00 e 0,25 para a razão entre a variância ambiental entre parcelas e a variância ambiental entre plantas dentro da parcela, respectivamente para ambas as características, foram adequados para a estimação dos parâmetros genéticos. Verificou-se a existência de variabilidade genética na população Dura para as duas características avaliadas. A seleção combinada, tanto baseada nos valores fenotípicos ou fundamentada na estatística $P_{i}$, proporcionou maiores ganhos genéticos. Embora a seleção entre e dentro de famílias tenha proporcionado ganhos satisfatórios, recomendase o processo de seleção baseado na estatística $P_{i}$, pois a mesma irá traduzir o verdadeiro potencial produtivo dos genótipos avaliados e a sua estabilidade de comportamento.

Palavras-chave: Elaeis guineensis Jacq., teste de famílias, estratégias de seleção, estatística $P_{i}$.

\section{INTRODUCTION}

Oil palm (Elaeis guineensis Jacq.) is a palm tree native of Africa, whose economic importance is mainly due to the oil production. Oil from the oil palm stands out for the use in food and for its medicinal properties and is used in different industrial sectors. Oil palm adapts very well to the tropical wet climate, where precipitation is high and well-distributed over the course of the year (PANDOLFO, 1981). It is a

\footnotetext{
Instituto Nacional Autónomo de Investigaciones Agropecuarias (INIAP), Santo Domingo de Los Colorados, Equador. IIPrograma de Pós-graduação em Genética e Melhoramento, Departamento de Biologia Geral, Universidade Federal de Viçosa (UFV), Viçosa, MG, Brasil.

IIIDepartamento de Biologia Geral, UFV, 36570-000, Viçosa, MG, Brasil. E-mail: cdcruz@ufv.br. Autor para correspondência.

${ }^{\text {IV }}$ Departamento de Fitotecnia, UFV, Viçosa, MG, Brasil.

vEmbrapa, Centro de Pesquisa Agroflorestal, Rondônia, RO, Brasil.
} 
perennial and monoecious tree that attains a height of $15 \mathrm{~m}$. Oil is extracted in two ways: from the pulp (mesocarp) or the nuts (palm kernel oil) (QUESADA, 2000). Among the oleaginous plants, oil palm is the most auspicious, due to its high mean annual oil yield of $3.7 \mathrm{t} \mathrm{ha}^{-1}$ - a rather impressive value when compared to the mean oil yield of soybean $\left(0.39 \mathrm{t} \mathrm{ha}^{-1}\right)$ or of peanut (0.86t ha-1) (MPOPC, 2002).

The genetic oil palm improvement is young compared to other agroindustrial fruit species such as coffee, grape or coconut. The improvement process is based on the yield of the commercial hybrid Tenera, which has a high yield potential, vegetative vigor and oil quality, besides other morpho-physiologic aspects. For the establishment of superior hybrids it is necessary to cross female Dura and male Pisifera parents, selected for good performance, with high general and specific combining ability.

One of the strategies adopted in improvement programs are family tests, whose procedure is based on the selection or elimination of entire families, taking the deviation of the phenotypic value of the family in relation to the mean phenotypic value of the population into consideration. Once the families are chosen, the selection among them considers those plants superior that present the largest deviations from the phenotypic values in relation to the mean phenotypic value of the population (SILVA, 1982). However, selection among and within families has the drawback of allowing the exclusion of potentially superior plants of intermediate families or intermediate plants of superior families.

The genotypic value of a plant is not the only information on its genetic potential, according to FALCONER \& MACKAY (1996). These authors reinforce the need to obtain additional information on the phenotypic values of parents, mainly of full or halfsibs, to improve estimations on the performance of a plant under selection. In this setting, combined selection is an alternative method of identification of superior genotypes, since it uses information on the family and the plant within the family. The combined selection generally considers that the phenotypic value of a plant, measured as deviation from the population mean, can be established by the linear combination of information on itself and on other parents.

One of the chief difficulties in improvement programs of any species at any stage is the genotype $x$ environment interaction. The use of varieties of good phenotype performance is recommendable, that is, varieties with good performance and minimal phenotypic fluctuations when cultivated in different environments. Among the different evaluation methodologies for the performance of varieties, we cite that of LIN \& BINNS (1988). In this methodology, the non-parametric $\mathrm{P}_{\mathrm{i}}$ statistic is used as measure to estimate the variety stability and adaptability, defined by the mean square of the distance between the variety mean in a particular environment and the maximum mean response obtained in that environment. $\mathrm{P}_{\mathrm{i}}$ therefore has the property of variance and weight the deviations of variety performance across the environments (years and/or sites) effectively, or even considers the performance stability (CRUZ \& CARNEIRO, 2003). We propose the use of the information created by the $P_{i}$ statistic for each genotype, in order to help the breeder choose the genotypes that demonstrated the highest yield potential and stability in the phenotypic evaluations in different environments.

On this background, the genetic gains obtained with combined selection and selection among and within families were compared in trials with Dura full-sib families, based on the information derived from phenotypic data and of those obtained with the $\mathrm{P}_{\mathrm{i}}$ statistic.

\section{MATERIAL AND METHODS}

Five full-sib families derived from the crossing Dura x Dura were evaluated in randomized blocks, with five replicates and 12 plants per plot. The trees were planted in equilateral triangles in a spacing of nine meters. The experiment comprised 300 plants on a useful area of 2.5 hectares. The trial was installed in 1989, in the experimental station of Santo Domingo de Los Colorados (Instituto Nacional Autónomo de Investigaciones Agropecuarias - INIAP), in Ecuador, at the level of the $38 \mathrm{~km}$ mark on the Quinindé highway (latitude $00^{\circ} 06^{\prime} \mathrm{N}$, longitude $79^{\circ} 20^{\prime} \mathrm{W}$ and height of $300 \mathrm{~m}$ asl).

The traits total number of bunches year ${ }^{-1}$ and total fruit yield year-1 $(\mathrm{kg})$ were evaluated at the plant level in the third year of the oil palm trees, from 1992 to 96, totaling five annual successive harvests.

The analysis of variance was performed for each trait. Due to the loss of some plants, a mean value was used for the number of plants per plot, given by the harmonic mean $(\bar{n}=10.9416)$, for the estimation of some variance components. This alternative is appropriate when the number of missings is small (RAMALHO et al., 2000). In this case the analysis of variance is performed similarly to a balanced experiment.

The estimates of the variance components, variation and heritability coefficients were obtained according to VENCOVSKY \& BARRIGA (1992). The 
following indices were established on the underlying variation coefficients: $\omega_{1}=\mathrm{CV}_{\mathrm{g}} / \mathrm{CV}_{\mathrm{e}} ; \omega_{2}=\mathrm{CV}_{\mathrm{gf}} / \mathrm{CV}_{\mathrm{e}}$ and $\omega_{3}=\mathrm{CV}_{\mathrm{gp}} / \mathrm{CV}_{\mathrm{e}}$, where $\mathrm{CV}_{\mathrm{g}}$ is the coefficient of genetic variation of the experiment; $\mathrm{CV}_{\mathrm{gf}}$ is the genetic variation coefficient among families; $\mathrm{CV}_{\mathrm{gp}}$ is the genetic variation coefficient among plants within plots; and $\mathrm{CV}_{\mathrm{e}}$ is the environmental variation coefficient. The estimation of the parameters $\omega_{1}, \omega_{2}$ and $\omega_{3}$ helped detect the experimental genetic variability among and within families, respectively, in the evaluated population. To obtain the estimates of additive variance $\hat{\sigma}^{2} \mathrm{~A}$ and variance caused by dominance deviations $\hat{\sigma}^{2}{ }_{\mathrm{D}}$ five values expressing the relation between the environmental variance among plots and the environmental variance among plants within the plot $(\theta)$ of $0.25,0.50,1.0,2.0$ and 4.0 were established.

The prediction of the total genetic gain obtained with the selection among and within families for each one of the traits, is given by the following expressions:

$$
\hat{\mathrm{G}}_{\mathrm{T}}=\left(\mathrm{SD}_{\mathrm{f}} \cdot \hat{\mathrm{h}}_{\mathrm{nfs}}\right)+\left(\mathrm{SD}_{\mathrm{fs}} \cdot \hat{\mathrm{h}}_{\mathrm{np}}\right)
$$

and $\hat{\mathrm{G}}_{\mathrm{T}}(\%)=\frac{\hat{\mathrm{G}}_{\mathrm{T}}}{\overline{\mathrm{Y}}} \times 100$, where $\hat{\mathrm{G}}_{\mathrm{\Gamma}}$ is the total estimated gain; $\mathrm{SD}_{\mathrm{f}}$ is the selection differential based on the family means; $\mathrm{SD}_{\mathrm{fs}}$ is the mean selection differential practiced within each selected family, $\hat{\mathrm{h}}_{\mathrm{nfs}}$ is the estimate of the narrow-sense heritability in full-sib families; $\hat{h}_{n p}$ is the estimate of the narrow-sense heritability in plants within full-sib families; and $\bar{Y}$ is the overall mean for the trait under selection.

Forty percent of the families (two families) and $35 \%$ of the plants within each one of the selected families (40 plants) were selected. For the combined selection, the plant-related index was estimated for each trait as proposed by PIRES (1996):

$$
\mathrm{IC}_{\mathrm{ijk}}=\mathrm{c}_{1}\left(\mathrm{Y}_{\mathrm{ijk}}-\overline{\mathrm{Y}}_{\mathrm{j} .}\right)+\mathrm{c}_{2}\left(\overline{\mathrm{Y}}_{\mathrm{i} . .}-\overline{\mathrm{Y}}_{\ldots}\right),
$$

where $\mathrm{IC}_{\mathrm{ijk}}$ is the estimator of the genetic value of the $\mathrm{k}^{\text {th }}$ plant, of the $\mathrm{i}^{\text {th }}$ family, of the $\mathrm{j}^{\text {th }}$ block; $\mathrm{Y}_{\mathrm{ijk}}$ is the phenotypic value of plant $i j k \bar{Y}_{j}$ is the mean of the block to which plant ijk belongs; $\overline{\mathrm{Y}}_{\mathrm{i}}$ is the mean of family $\mathrm{i}$; $\bar{Y}_{\text {... }}$ is the overall mean of the families; $c_{1}$ is the weight of the individual phenotypic value; $\mathrm{c}_{2}$ is the weight of the phenotypic value of the family mean.

The response to combined selection was estimated by

$$
\hat{\mathrm{G}}_{\mathrm{CS}}=\frac{\operatorname{Côv}\left(\mathrm{CI}_{\mathrm{ijk}}, \mathrm{g}_{\mathrm{ijk}}\right)}{\hat{\mathrm{V}}\left(\mathrm{CI}_{\mathrm{ijk}}\right)},
$$

where $\hat{G}_{\mathrm{CS}}$ is the estimate of the genetic gain with combined selection; Côv $\left(\mathrm{CI}_{\mathrm{ijk}}, \mathrm{g}_{\mathrm{ijk}}\right)$ is the estimate of the additive genetic covariance between the scores of the combined selection index and the respective genetic values of the plants; $\hat{\mathrm{V}}\left(\mathrm{CI}_{\mathrm{ijk}}\right)$ is the variance of the selection index values; $\mathrm{SD}_{\mathrm{CS}}$ is the selection differential, obtained through the scores of the combined index. It is known that, $\mathrm{CôV}\left(\mathrm{CI}_{\mathrm{ijk}}, \mathrm{g}_{\mathrm{ijk}}\right)=$ $\hat{\mathrm{V}}\left(\mathrm{CI}_{\mathrm{ijk}}\right)$; so the estimator of the genetic gain with combined selection is given by $\hat{\mathrm{G}}_{\mathrm{CS}}=\mathrm{SD}_{\mathrm{CS}}$.

In the two applied methods, selection was also based on the phenotypic performance of families and plants, given by the $\mathrm{P}_{\mathrm{i}}$ statistic (LIN \& BINNS, 1988). The statistic was defined by the following expression: $\quad P_{i k}=\frac{\sum_{i=1}^{5}\left(y_{i k 1}-M_{1}\right)^{2}}{2 a}$, where $P_{i k}$ is the estimator of the potential yield of the $\mathrm{k}^{\text {th }}$ plant of family i ( $\mathrm{i}=1,2,3,4,5) ; \mathrm{y}_{\mathrm{ikl}}$ is the observed value of plant $\mathrm{k}$, of family $\mathrm{i}$, in harvest $\mathrm{l}$ $(l=1,2,3,4,5) ; M_{1}$ is the maximum value among all plants of harvest l; and a is the number of harvests.

The selection techniques were in the sense of increment of the two traits. The acronym SAW was coined for the selection among and within families and CS for the combined selection. Finally, the coefficients of coincidence between CS and SAW were evaluated for a sample of 40 superior plants. The software package GENES (CRUZ, 2001) was used for all statistical analyses.

\section{RESULTS AND DISCUSSION}

An inherent problem of family tests with information on plants within a plot, principally with perennial species, is the occurrence of the competition effect between plants, resulting in a lower mean square of the source of variation among plots than the mean square of the source of variation within plots. By the results of the analysis of variance (Table 1), this fact was not verified. We therefore suggest a spacing of 9x9x9 as adequate for the establishment of comparisons regarding the genotypic superiority among oil palm trees.

For annual or perennial species whose spacing is the same between rows and between plants within rows, as in the example of the spacing used in this study, one may presume the value of the ratio between the environmental variance among plots and the environmental variance among plants within the plot $(\theta)$ is equal to one (CRUZ \& CARNEIRO, 2003). For the trait total fruit yield year ${ }^{-1}$ the best value of $\theta$ 
Table 1 - Summary of the analysis of variance and estimates of genetic and non-genetic parameters, for total number of bunches year ${ }^{-1}$ and total fruit yield year ${ }^{-1}$, evaluated in five full-sib families derived from the oil palm crossing Dura x Dura (E. guineensis Jacq).

\begin{tabular}{|c|c|c|c|}
\hline \multirow[b]{2}{*}{ Source of variation } & \multirow[b]{2}{*}{ GL } & \multicolumn{2}{|c|}{ Mean square } \\
\hline & & total number of bunches year ${ }^{-1}$ & total fruit yield year ${ }^{-1}$ \\
\hline blocks & 4 & 2486.33 & 272000.60 \\
\hline families & 4 & $3006.72^{*}$ & $159751.6^{*}$ \\
\hline among plots & 16 & 830.99 & 57954.32 \\
\hline within plots & 257 & 131.24 & 18224.55 \\
\hline \multicolumn{4}{|l|}{ genetic parameters } \\
\hline$\hat{\sigma}_{\mathrm{b}}^{2}$ & & 30.26 & 3912.52 \\
\hline$\hat{\sigma}_{\mathrm{ga}}$ & & 39.77 & 1860.73 \\
\hline$\hat{\sigma}_{g w}$ & & 67.32 & 3702.67 \\
\hline$\hat{\sigma}_{p}$ & & 131.24 & 18224.55 \\
\hline$\hat{\sigma}_{\mathrm{e}}^{2}$ & & 63.95 & 3631.07 \\
\hline$\hat{\sigma}_{\text {phfs }}$ & & 54.96 & 2920.07 \\
\hline$\hat{\sigma}_{\mathrm{A}}^{2}$ & & 52.02 & 1881.91 \\
\hline$\hat{\sigma}_{\mathrm{D}}^{2}$ & & 55.04 & 3679.08 \\
\hline$\hat{\sigma}_{\mathrm{D}}^{2} / \hat{\sigma}_{\mathrm{A}}^{2}$ & & 1.06 & 1.96 \\
\hline$\hat{\mathrm{h}}_{\mathrm{bfs}}(\%)$ & & 72.36 & 63.72 \\
\hline$\hat{\mathrm{h}}_{\mathrm{bp}}(\%)$ & & 51.29 & 20.31 \\
\hline $\mathrm{CV}_{\mathrm{e}}(\%)$ & & 17.51 & 12.64 \\
\hline $\mathrm{CV}_{\mathrm{g}}(\%)$ & & 22.66 & 15.64 \\
\hline $\mathrm{CV}_{\mathrm{gf}}(\%)$ & & 13.81 & 9.04 \\
\hline $\mathrm{CV}_{\mathrm{gp}}(\%)$ & & 17.97 & 12.76 \\
\hline$\omega_{1}$ & & 1.29 & 1.24 \\
\hline$\omega_{2}$ & & 0.78 & 0.72 \\
\hline$\omega_{3}$ & & 1.03 & 1.01 \\
\hline
\end{tabular}

${ }^{*}(\mathrm{P}<0.10)$

$\hat{\sigma}_{\mathrm{b}}^{2}=$ estimate of the component of environmental variance due to the differences between blocks, $\hat{\sigma}_{\mathrm{ga}}=$ estimate of the component of genotypic variance among the means of the full-sib families, $\hat{\sigma}_{\mathrm{gw}}=$ estimate of the component of genotypic variance within families, $\hat{\sigma}_{\mathrm{p}}=$ estimate of the component of phenotypic variance among plants within plots, $\hat{\sigma}_{\mathrm{e}}^{2}=$ estimate of the component of environmental variance among plots, $\hat{\sigma}_{\text {phfs }}=$ estimate of the component of phenotypic variance among family means, $\hat{\sigma}_{\mathrm{A}}^{2}=$ estimate of the component of additive variance, $\hat{\sigma}_{\mathrm{D}}^{2}=$ estimate of the component of variance due to dominance deviations, $\hat{\mathrm{h}}_{\mathrm{bfs}}=$ estimate of the broad-sense heritability in the family means, $\hat{\mathrm{h}}_{\mathrm{bp}}=$ estimate of the broad-sense heritability within families; $\mathrm{CV}_{\mathrm{e}}=$ coefficient of environmental variation, $\mathrm{CV}_{\mathrm{g}}=$ coefficient of genotypic variation; $\mathrm{CV}_{\mathrm{gf}}=$ coefficient of genotypic variation among families, $\mathrm{CV}_{\mathrm{gp}}=$ coefficient of genotypic variation within families; $\omega_{1}=\mathrm{CV}_{\mathrm{g}} / \mathrm{CV}_{\mathrm{e}}, \omega_{2}=\mathrm{CV}_{\mathrm{gg}} / \mathrm{CV}_{\mathrm{e}}$ and $\omega_{3}=\mathrm{CV}_{\mathrm{gp}} / \mathrm{CV}_{\mathrm{e}}$. 
was 1.0. For the trait total number of bunches year-1 however the best value $\theta$ was equal to 0.25 . These values were chosen because they provided heritability estimates of reasonable magnitudes, that is, that did not exceed $100 \%$ and/or were not negative (data not shown). We emphasize that these values are peculiar to the present study, which does not mean that they cannot be considered as basis for the conduction of other analyses.

By the analysis of variance (Table 1) the existence of genetic variability was detected among full-sib families for the total number of bunches year ${ }^{-1}$. The existence of genetic variability for the total fruit yield was also observed.

Compared to the genetic variation coefficients, the relations $\omega$ are not influenced by the trait mean and have the advantage of showing the real magnitude of the increase of a trait in a group of plants under study (VENCOVSKY, 1987). MISTRO et al. (2004) reported that when the index $\omega$ has a value equal or superior to 1.0 the conditions are highly favorable for selection. The existence of genetic variability can be confirmed by values of $\omega 1$ for the two evaluated traits. According to the values of $\omega_{2}, \omega_{3}, \hat{\sigma}_{\mathrm{gw}}$ and $\hat{\sigma}_{\mathrm{ga}}$ a greater genetic variability was stated within families. This fact might be related to the small number of families in use. Low $\mathrm{CV}_{\mathrm{e}}$ values were verified for the two evaluated traits, expressing good experimental precision (Table 1)

The broad-sense heritability in family means ( $\hat{\mathrm{h}}_{\mathrm{bfs}}$ ), for the total fruit yield year ${ }^{-1}$ as much as for the total number of bunches year ${ }^{-1}$, was superior to the broad-sense heritability within families $\left(\hat{\mathrm{h}}_{\mathrm{bp}}\right)$. The selection differential within families naturally tends to be higher than the differential among families, which can result in higher genetic gains. However, in any selection process, the heritability value must be always taken into consideration, since it means the accuracy of the method in use. For both traits, the variance due to dominance deviations $\left(\hat{\sigma}_{\mathrm{D}}^{2}\right)$ was superior to the additive genetic variance $\left(\hat{\sigma}_{\mathrm{A}}^{2}\right)$, which confirms the importance of $\left(\hat{\sigma}_{\mathrm{D}}^{2}\right)$ in oil palm improvement programs, especially the ones that aim at the production of singlecross hybrids and clone material.

Table 2 presents the estimates of genetic gains based on phenotypic data and the $\mathrm{P}_{\mathrm{i}}$ statistic, for the methods of combined selection (CS) and selection among and within families (SAW). It was observed that the genetic gain among families was higher compared to the gain within families for both traits, although the selection differential within families $\left(\mathrm{SD}_{\mathrm{fs}}\right)$ was superior to the differential among families $\left(\mathrm{SD}_{\mathrm{f}}\right)$.
When using the phenotypic observations and the estimates of the phenotypic performance $\left(\mathrm{P}_{\mathrm{i}}\right.$ statistic) there was no difference in the family selection, which justifies the use of the same information for the selection differential $\left(\mathrm{SD}_{\mathrm{f}}\right)$ for both study traits. The genetic gains based on the phenotypic observations for the selection within families were slightly superior to those obtained with the $P_{i}$ statistic. The genetic gains ( $G_{\mathrm{af}}, \mathrm{G}_{\mathrm{wf}}, \mathrm{G}_{\mathrm{T}}$ and $\mathrm{G}_{\mathrm{CS}}$ ) obtained for total number of bunches all exceeded those obtained with the total fruit yield. The option of indirect selection by means of the number of bunches to increase the fruit yield is not the most adequate solution owing to the negative genetic correlation (-0.61) between the two traits, indicating that an increase in the number of bunches leads to a production reduction. It is believed that a negative selection for the number of bunches would be the most appropriate strategy. However, in the first years of production, bunches are small and abundant. As the plant develops, the bunches become larger, heavier and less, thus producing higher yields (LIM \& TOH, 1985; HENSON, 1993). The quality improvement of the bunches would be the most appropriate alternative to increase the yield and the fruit yield indirectly.

With the combined selection, genetic gains of $16.68 \%$ and $15.36 \%$ were obtained for the total number of bunches, based on the phenotypic values and on the $\mathrm{P}_{\mathrm{i}}$ statistic, respectively. For the total fruit yield the gains were $4.92 \%$ and $4.77 \%$, based on the phenotypic values and the $\mathrm{P}_{\mathrm{i}}$ statistic, respectively.

In relation to the efficiency of the selection strategies, it was verified that CS was more effective than SAW in all situations (Table 2). Likewise, the efficiency of the combined selection was stated by MORAIS (1992), PIRES (1996) and MARTINS et al. (2005). However, SAW also achieved satisfactory genetic gains, which justifies its application as instrument of ranking of candidate families and plants for selection.

The use of the $P_{i}$ statistic in the selection strategies must not be seen as a variable transformation but rather as a genotypic estimator of the performance. Although the price of lower genetic gains has to be paid when using the $\mathrm{P}_{\mathrm{i}}$ statistic, this fact ought to be disregarded, even when the selected families or plants present lower genetic values, since the reliability of the selected genotypes is greater. This way, families or plants are selected that present the highest yield potential and stability in the evaluated environments (years and/or locations), known as temporal stability.

There was a very good agreement among plants selected by CS, based on the phenotypic values (I), and CS based on the $\mathrm{P}_{\mathrm{i}}$ statistic(II), as well as in the 
Table 2 - Estimates of the genetic gains with selection among and within families and combined selection for total number of bunches year ${ }^{-1}$ and total fruit yield year ${ }^{-1}$, based on the phenotypic values (I) and based on the $\mathrm{P}_{\mathrm{i}}$ statistic (II).

\begin{tabular}{|c|c|c|c|c|}
\hline \multirow{2}{*}{ Genetic parameters } & \multicolumn{2}{|c|}{ total number of bunches year ${ }^{-1}$} & \multicolumn{2}{|c|}{ total fruit yield year ${ }^{-1}$} \\
\hline & I & $\mathrm{II}^{2 /}$ & I & II \\
\hline \multicolumn{5}{|l|}{ among families } \\
\hline overall mean & 45.66 & - & 476.92 & - \\
\hline mean of the selected families & 54.72 & - & 520.68 & - \\
\hline $\mathrm{SD}_{\mathrm{f}}$ & 9.06 & - & 43.76 & - \\
\hline$\hat{\mathrm{h}}_{\mathrm{nfs}}(\%)$ & 47.33 & - & 32.22 & - \\
\hline$\hat{\mathrm{G}}_{\mathrm{af}}$ & 4.29 & - & 14.10 & - \\
\hline $\begin{array}{l}\hat{\mathrm{G}}_{\mathrm{af}}(\%) \\
\text { within families }\end{array}$ & 9.39 & - & 2.96 & - \\
\hline $\mathrm{SD}_{\mathrm{fs}}$ & 13.40 & 13.28 & 134.73 & 132.83 \\
\hline$\hat{\mathrm{h}}_{\mathrm{np}}(\%)$ & 19.82 & - & 5.16 & - \\
\hline$\hat{\mathrm{G}}_{\mathrm{wf}}$ & 2.66 & 2.63 & 6.96 & 6.85 \\
\hline$\hat{\mathrm{G}}_{\mathrm{wf}}(\%)$ & 5.82 & 5.76 & 1.46 & 1.44 \\
\hline \multicolumn{5}{|l|}{ among and within families (SAW) ${ }^{1 /}$} \\
\hline$\hat{\mathrm{G}}_{\mathrm{T}}$ & 6.95 & 6.92 & 21.06 & 20.95 \\
\hline$\hat{\mathrm{G}}_{\mathrm{T}} \hat{\mathrm{G}}_{\mathrm{T}}(\%)$ & 15.21 & 15.15 & 4.42 & 4.39 \\
\hline \multicolumn{5}{|l|}{ combined selection (CS) } \\
\hline$\hat{\mathrm{c}}_{1}$ & 0.1520 & $n e^{3 /}$ & 0.0488 & ne \\
\hline$\hat{\mathrm{C}}_{2}$ & 0.3366 & ne & 0.2849 & ne \\
\hline$\hat{\mathrm{G}}_{\mathrm{CS}}$ & 7.62 & 7.01 & 23.47 & 22.77 \\
\hline$\hat{\mathrm{G}}_{\mathrm{CS}}(\%)$ & 16.68 & 15.36 & 4.92 & 4.77 \\
\hline selection efficiency $=\mathrm{CS} / \mathrm{SAW}$ & 1.10 & 1.01 & 1.11 & 1.08 \\
\hline
\end{tabular}

${ }^{1 /}$ Selection practiced in the two best families and in 40 plants within the selected families.

${ }^{2 /}$ Fields with a dash represent values equal to those of the adjacent column.

${ }^{3 /}$ Not estimated.

$\mathrm{SD}_{\mathrm{f}}$ is the selection differential based on the family means; $\hat{\mathrm{h}}_{\mathrm{nfs}}$ is the estimate of the narrow-sense heritability in the full-sib families; $\hat{\mathrm{G}}_{\mathrm{af}}$ is the estimate of the genetic gain among families; $\mathrm{SD}_{\mathrm{fs}}$ is the mean selection differential practiced within each family; $\hat{\mathrm{h}}_{\mathrm{np}}$ is the estimate of the heritability in the narrow-sense among plants within the full-sib families; $\hat{G}_{w f}$ is the estimate of the genetic gain within families; $\hat{G}_{\mathrm{T}}$ is the total estimated gain; $\hat{\mathrm{C}}_{1}$ is the estimated weight of the individual phenotypic value; $\hat{\mathrm{C}}_{1}$ is the estimated weight of the phenotypic value of the family mean and $\hat{G}_{\mathrm{CS}}$ is the estimate of the genetic gain by the combined selection.

SAW between the strategies I and II (92.50\%). There was a moderate concordance in the methods CS (I) with SAW (I)/SAW (II) and CS (II) with SAW (I)/SAW (II) of 67.50 and $70.00 \%$, respectively (data not shown). A particularity of the CS (I) was the capacity of selecting amongst the 40 plants one of the unselected family, although the CS (II) had not selected it. Probably, the greater selection efficiency of the combined selection is particularly the fact of including a greater number of families for future recombinations, maximizing the expected genetic gain (MARTINS et al., 2005).

The superiority of CS in relation to SAW was demonstrated by RESENDE (2002). Among the advantages of the combined selection he points out: (i) superiority in situations of low heritability values and low selection intensity (which can also mean a smaller experimental population size and lower number of families) and (ii) tendency of providing a smaller 
effective population size $\left(\mathrm{N}_{\mathrm{e}}=4 \mathrm{~N} / \sigma_{\mathrm{n}}^{2}+2\right)$, since the number of plants selected per family is variable $\left(\sigma_{\mathrm{n}}^{2}\right)$, so that in SAW this variance is equal to zero, where $\mathrm{N}$ is the number of selected plants.

The evaluation of a larger number of families could result in greater discordances between the selected plants and families, with the use of $\mathrm{P}_{\mathrm{i}}$ statistic as well as with the phenotypic data. However, the values of accuracy for the difference between the selection among and within families and combined selection (SAW - CS), did practically not vary with the variation of the number of plants per family (RESENDE, 2002).

\section{CONCLUSIONS}

The efficiency of the combined selection to provide higher genetic gains than selection among and within full-sib families Dura was confirmed, although satisfactory gains had been obtained with the selection among and within as well.

The $\mathrm{P}_{\mathrm{i}}$ statistic is an important selection criterion whose use ought to be recommended in selection strategies, since, apart from expressing the yield potential of the genotypes, it evaluates their performance stability.

\section{ACKNOWLEDGEMENTS}

The authors would like to thank the CNPq for the scholarships and for granting financial support.

\section{REFERENCES}

CRUZ, C.D.; CARNEIRO, P.C.S. Modelos biométricos aplicados ao melhoramento genético. Viçosa: UFV, 2003. v. $2,585 p$

CRUZ, C.D. Programa GENES: versão Windows, aplicativo computacional em genética e estatística. Viçosa: UFV, 2001. $648 p$.

FALCONER, D.S.; MACKAY, T.F. Introduction to quantitative genetics. London: Longman, 1996. 438p.

HENSON, Y.E. Factors determining mesocarp oil bunch ratio in the oil palm: A physiological perspective. In: NATIONAL SEMINAR ON PALM OIL EXTRACTION RATE: PROBLEMS AND ISSUES. Kuala Lumpur, 1993. Proceedings... Malaysia: Palm Oil Research Institute of Malaysia, 1993. p.27-35.

LIM, K.H.; TOH, P.Y. The accuracy and precision of bunch analysis. In: SYMPOSIUM ON IMPACT OF THE
POLLINATING WEEVIL ON THE MALAYSIAN OIL PALM INDUSTRY. Kuala Lumpur, 1985. Proceedings... Malaysia: Kementerian Perusahaan Utama, 1985. p.91-109.

LIN, C.S.; BINNS, M.R. A superiority measure of cultivar performance for cultivar $\mathrm{x}$ location data. Canadian Journal of Plant Science, Ottawa, v.68, n.1, p.193-8, 1988.

MALAYSIAN PALM OIL PROMOTION COUNCIL. Palm oil link. Datuk Haron Siraj. Malaysia: MPOPC, 2002. v.12, 13p.

MARTINS, I.S. et al. Comparação entre os processos de seleção entre e dentro e o de seleção combinada, em progênies de Eucalyptus grandis. Cerne, Lavras, v.11, n.1, p.16-24, 2005

MISTRO, J.C. et al.. Estimates of genetic parameters and expected genetic gains with selection in robust coffee. Crop Breeeding and Applied Biotechnology, v.4, n.1, p.86-91, 2004.

MORAIS, O.P. Análise multivariada da divergência genética dos progenitores, índices de seleção e seleção combinada numa população de arroz oriunda de intercruzamentos, usando macho-esterilidade. 1992. 251f. Tese (Doutorado em Genética e Melhoramento) - Curso de Pós-graduação em Genética e Melhoramento, Universidade Federal de Viçosa.

PANDOLFO, C. A cultura do dendê na Amazônia. Belém: SUDAM, 1981. 35p.

PIRES, I.E. Eficiência da seleção combinada no melhoramento genético de Eucalyptus spp. 1996. $116 \mathrm{f}$. Tese (Doutorado em Genética e Melhoramento) - Curso de Pós-graduação em Genética e Melhoramento, Universidade Federal de Viçosa.

QUESADA, G. Cultivo e industria de la palma africana. Programa Nacional de Palma Africana. Documento preliminar para guia del productor. [s.l.: s.n.], 2000. 92p.

RAMALHO, M.A.P. et al.. Experimentação em genética e melhoramento de plantas. Lavras: UFLA, 2000. 303p.

RESENDE, M.D.V. Genética biométrica e estatística no melhoramento de plantas perenes. Brasília: Embrapa Informação tecnológica, 2002. 975p.

SILVA, M.A. Melhoramento animal (Métodos de seleção). Viçosa: UFV, 1982. 51p.

VENCOVSKY, R.; BARRIGA, P. Genética biométrica no fitomelhoramento. Ribeirão Preto: SBG, 1992. 406p.

VENCOVSKY R. Herança quantitativa. In: PATERNIANI, E.; VIEGAS, G. P. (eds) Melhoramento e produção do milho. 2 ed. Campinas: Fundação Cargill, 1987. v.1, cap.5, p.137-214. 